\title{
Agronomic traits and deoxynivalenol contamination of two tetraploid wheat species (Triticum turgidum spp. durum, Triticum turgidum spp. turanicum) grown strictly under low input conditions
}

\author{
Giovanni Dinelli, Raffaella Di Silvestro, Ilaria Marotti, Sara Bosi, Valeria Bregola, \\ Alessandro Di Loreto, Paola Nipoti, Antonio Prodi, Pietro Catizone \\ Department of Agricultural Sciences, University of Bologna, Italy
}

\begin{abstract}
An evaluation of the agronomic performance of two tetraploid wheat varieties (Triticum turgidum spp. durum, Claudio; Triticum turgidum spp. turanicum, Kamut ${ }^{\circledR}$ ) grown strictly under low input conditions was carried out over three consecutive cropping years. The study reported grain yield values ranging from 1.8 to $2.6 \mathrm{t} \mathrm{ha}^{-1}$. Productivity showed to be primarily affected by environmental conditions, while no differences were observed between the two genotypes. The study of the yield components highlighted that the durum wheat variety had a higher plant density than Kamut ${ }^{\circledR}$, but this discrepancy was offset by a greater number of kernels per spike and the kernel weight of khorasan wheat. The investigated wheat genotypes were also analysed to assess the mycotoxin (DON) levels of wholegrain semolina and the efficiency of cleaning treatments to reduce contamination. Results showed that both wheat varieties had a good hygienic and sanitary quality with a DON content ranging from 0.35 to $1.31 \mathrm{mg} \mathrm{kg}^{-1}$, which was lower than the maximum acceptable level set by the European regulation at 1.75 $\mathrm{mg} \mathrm{kg}-1$. In addition, our research work investigated the effects of premilling cleaning procedures, such as water washing and brushing, on mycotoxin levels, which yielded interesting results in terms of decontamination efficiency. These methods were particularly efficient with
\end{abstract}

Correspondence: Giovanni Dinelli, Department of Agricultural Sciences, University of Bologna, via Fanin 44, 40127 Bologna, Italy.

E-mail: giovanni.dinelli@unibo.it

Key words: durum wheat, kamut, mycotoxins, organic agriculture, organic wheat production.

Acknowledgements/Funding: the authors are grateful to Kamut International (USA) for the financial support to this research project.

Conference presentation: SIA XLII Congress, Reggio Calabria, 2013.

Received for publication: 10 February 2014.

Revision received: 11 April 2014.

Accepted for publication: 30 May 2014.

@C Copyright G. Dinelli et al., 2014

Licensee PAGEPress, Italy

Italian Journal of Agronomy 2014; 9:583

doi:10.4081/ija.2014.583

This article is distributed under the terms of the Creative Commons Attribution Noncommercial License (by-nc 3.0) which permits any noncommercial use, distribution, and reproduction in any medium, provided the original author(s) and source are credited.
Kamut $^{\circledR}$ semolina (46-93\% DON reduction), suggesting that mycotoxins accumulate in this variety at more superficial levels than in the durum wheat variety. On the whole, our study provided additional knowledge on the traits to be further improved to respond to low input requirements and to enhance the potential adaptability of wheat genotypes to organic agriculture. Our results emphasized the need to develop wheat varieties that can provide adequate performance without high levels of nitrogen inputs by selecting specific traits, such as kernel weight, spike length and kernel/spike. This may help achieve productivity gains in organic systems.

\section{Introduction}

In Italy, the organic farming sector involves 49,146 operators, of which 40,146 are producers. The area under organic farming increased by $6.4 \%$ in 2012 over 2011 and amounted to 1,167,362 hectares. About $8 \%$ of the total organic arable land was dedicated to the production of durum wheat (Triticum turgidum spp. durum), i.e. 87,795 ha, while common organic wheat (Triticum aestivum L.) was cultivated on 26,347 ha (ISMEA, 2012). The growth of organic farming has been directly driven by the increase in the market demand for organic products, which are now chosen by many consumers, who consider them healthier and more environmental-friendly compared with conventional ones. The demand for non-conventionally grown food and natural food has led to the investigation of new food sources for the development of specialty products. Italy has the highest pro capita consumption of pasta worldwide, which significantly contributes to the daily intake of macro- and micronutrients, such as starch, proteins, vitamins and mineral elements, in addition to several bioactive components, including dietary fibres and antioxidants (Fardet, 2010). Recently, ancient wheat varieties have attracted the attention of both scientists and consumers for their nutritional and health-promoting properties. Among old wheat genotypes, the khorasan wheat variety (Triticum turgidum spp. turanicum), generally sold under the commercial brand of Kamut ${ }^{\circledR}$, has been investigated to assess its bioactive properties (Benedetti et al., 2012; Marotti et al., 2012), but data concerning its agronomic performance in the Italian and European farmland are still limited (Grausgruber et al., 2005; Piergiovanni et al., 2009; Stagnari et al., 2008). Due to the tall-straw habitus, khorasan wheat is unsuitable to conventional agricultural management, since nitrogen inputs cause severe lodging problems. However, it may possess other useful traits, such as rusticity and competitiveness against weeds, which can play a key role under organic conditions (Lammerts van Bueren et al., 2011). Nowadays, the organic sector is lacking crop varieties that are specifically selected for low-input systems and significant efforts are still required to develop new wheat genotypes that may ensure a good performance in terms of yield and nutritional char- 
acteristics. Moreover, the mycotoxin contamination of flours is a significant source of concern in the organic sector, since no fungicide can be applied to the crops. The most common toxin occurring in wheat flours is deoxynivalenol (DON) that belongs to the trichothecene class and is produced by several fungi of the Fusarium genus (mainly F. culmorum and $F$. graminearum) (Edwards, 2009). Mycotoxins cause major safety problems in cereal production and are known to have adverse and chronic health impacts on humans and animals (Murphy et al., 2006). The DON levels are regulated by a decree issued by the European Commission Regulation No. 1126/2007 (European Commission, 2007) that sets the maximum allowed threshold values for unprocessed cereal and derived products ( 1.75 and $0.75 \mathrm{ppm}$ for unprocessed durum wheat and cereal flour, respectively). As DON is mainly accumulated in the bran, different strategies aimed at reducing mycotoxin contamination were investigated (i.e. sieving, sorting, cleaning and debranning procedures), but results showed variable levels of decontamination efficiency (Cheli et al., 2013). The aim of this study has been to evaluate the agronomic traits and productivity of two tetraploid wheat varieties (Triticum turgidum spp. durum, Claudio; Triticum turgidum spp. turanicum, Kamut $^{\circledR}$ ) grown strictly under low input conditions. In addition, the study also investigated the sanitary quality of the resulting wholegrain flour and how to improve it using appropriate cleaning procedures. This research activity will contribute to gain more knowledge of organic wheat production and the potential adaptability of diverse wheat genotypes to low-input agro-ecosystems.

\section{Materials and methods}

\section{Field experiments}

The field experiments were carried out over three consecutive growing seasons (2009/2010, 2010/2011, 2011/2012) using the Italian Claudio variety of durum wheat (Triticum turgidum spp. durum) and Kamut ${ }^{\circledR}$ khorasan wheat (Triticum turgidum spp. turanicum). The trials were conducted in a biodynamic farm named Podere Santa Croce (Argelato, Italy; $44^{\circ} 39^{\prime} 57^{\prime \prime} \mathrm{N}, 11^{\circ} 19^{\prime} 43^{\prime \prime} \mathrm{E}, 25 \mathrm{~m}$ asl). Each year, the two wheat varieties were sown in two adjacent plots of $5000 \mathrm{~m}^{2}$ with a sowing density of $180 \mathrm{~kg} \mathrm{ha}^{-1}$ by applying biodynamic techniques throughout the entire crop cycle. Also 2-year crop rotations with leguminous (i.e. Vicia faba L. var. minor), maize (Zea mays L.) and horticultural crops were carried out in each growing season. Neither pesticides, nor fertilizers, nor manure were applied throughout the crop cycles. Crops were treated exclusively with highly-diluted biodynamic treatments 500 (1 application before sowing) and 501 (1 application during flowering). Data on monthly mean temperature and total rainfall were recorded during each crop cycle (Figure 1). On the whole, the first cropping year (2009/2010) had the highest precipitation level. The maximum rainfall value was reached in February $(201.0 \mathrm{~mm})$, while 2010/2011 and 2011/2012 had much lower values (69.0 and $26.4 \mathrm{~mm}$, respectively). In springtime, the first and third year had similar rainfall levels (ranging from 55.2 to $76.6 \mathrm{~mm}$ ), while the second growing season was marked by drier conditions (15.9-47.4 mm). During the grain filling phase (June-July), the most abundant precipitation was again recorded in 2009/2010 (43.8-86.4 mm) in contrast with the extremely dry conditions of the following growing seasons. As regards the temperature, the third cropping year had the coldest winter, especially in February with a mean value of $-0.2^{\circ} \mathrm{C}$ (while $2009 / 2010$ and 2010/2011 had $6.3^{\circ} \mathrm{C}$ ) (Figure 1). The third growing season had also the coldest springtime with a monthly temperature comprised between 12.7 and $17.5^{\circ} \mathrm{C}$ on April and May, while the second year was the hottest (17.0$21.5^{\circ} \mathrm{C}$ ). In the final phase of the crop cycle, similar temperature values were recorded in June $\left(23.8-24.2^{\circ} \mathrm{C}\right)$, while in July in the second year the temperature was colder $\left(23.5^{\circ} \mathrm{C}\right)$ than in the first year and the third year ( 26.3 and $26.2^{\circ} \mathrm{C}$, respectively).

\section{Yield and grain quality parameters}

At maturity, plants were randomly collected in five areas $\left(2 \mathrm{~m}^{2}\right)$ within each experimental plot and measured for plant height $(\mathrm{cm})$, spike length $(\mathrm{cm})$, number of spikes per square meter, number of spikelets per spike, number of grains per spike and kernel weight (mg). In addition, for each $2 \mathrm{~m}^{2}$ area an assessment of the weed density was made, which included the identification of weed species identification and the measurement of the number of plants. Productivity was calculated on the basis of the whole experimental plot and data included grain yield $\left(\mathrm{t} \mathrm{ha}^{-1}\right)$, straw yield $\left(\mathrm{t} \mathrm{ha}^{-1}\right)$ and harvest index (HI) (ratio of grain yield to grain-plus-straw yield). The quality parameters took into account the test weight, which was measured using a Shopper chondrometer equipped with a $1 \mathrm{~L}$ container $\left(\mathrm{kg} \mathrm{hL}^{-1}\right)$, and the protein content $\left(\mathrm{g} \mathrm{kg}^{-1}\right)$ calculated by the Kjeldahl method $(\mathrm{N}=5.7)$ (American Association of Cereal Chemists, method 46-12) (AACC, 1995).

\section{Cleaning treatments of grains and mycotoxyn analysis}

Kamut $^{\circledR}$ and Claudio grain samples from the three growing seasons were stone-ground (100\% flour extraction) using a domestic stone mill (Billy 200, Hawos Mulini, Bad Homburg, Germany) and tested for the DON content using an AgraQuant@DON assay based on a direct competitive enzyme-linked immunosorbent assay (ELISA) (Romer Labs Inc., Union, M0, USA). The analyses were carried out on three replicates and results were expressed as $\mathrm{mg}$ per $\mathrm{kg}$ of wholegrain semolina. Moreover, grains harvested in 2009/2010 and 2010/2011 were submitted to two different cleaning procedures aimed at evaluating the effects of cleaning on semolina contamination. For both growing seasons, three replicates $(1 \mathrm{~kg})$ of Kamut ${ }^{\circledR}$ and Claudio grain samples were cleaned by immersing and shaking them in water for $1 \mathrm{~h}$. Water-cleaned grains were then air-dried until a $13 \%$ humidity was reached, stone ground (100\% flour extraction) and analysed to assess the mycotoxin content. Three replicates $(1 \mathrm{~kg})$ of Kamut ${ }^{\circledR}$ and Claudio grain samples were also cleaned by using a brushing machine at different frequency speeds (ranging from 20 to $90 \mathrm{~Hz}$ ). All brushed grains were stone-ground (100\% flour extraction) and analysed to assess the mycotoxin content.

\section{Statistical analyses}

The two-way analysis of variance (ANOVA) was used to assess the effect of genotype, cropping year and their interaction and impact on the agronomic traits and the micotoxyn content. The one-way ANOVA was used to determine differences among grain samples submitted to the different cleaning treatments separately for the 2009/2010 and 2010/2011 growing seasons. All analyses were carried out using Statistica 6.0 software (2001, StatSoft, Tulsa, OK, USA), while Tukey's Honestly Significant Difference test was used to determine differences between means at $\mathrm{P}<0.05$.

\section{Results and discussion}

\section{Agronomic traits}

The three years experimental trial showed a high heterogeneity in terms of weed density and composition. During the first year (2009/2010), weeds mainly consisted in Cirsum arvensis (7.6 and 12.4 plants per square meter for Kamut ${ }^{\circledR}$ and Claudio, respectively) and Rumex crispus ( 9.6 and 6.7 plants per square meter for Kamut ${ }^{\circledR}$ and Claudio, respectively) in addition to some gramineous species (i.e. 
Lolium multiflorum, Cynodon dactylon) (Figure 2). The lower plant density of Convolvolus arvensis in the Kamut ${ }^{\circledR}$ field suggested that the tall-straw habitus of this ancient genotype was more competitive against this weed species compared with the dwarf variety Claudio. An opposite result was observed with Bromus sterilis, which showed a larger infestation in the Kamut ${ }^{\circledR}$ field compared with the modern variety (4.9 and 0.9 plants per square meter, respectively). In 2010/2011, a different set of weeds was observed, as the most abundant infestation was by Avena fatua that reached values of 23.2 and 15.4 plants per square meter for Kamut ${ }^{\circledR}$ and Claudio, respectively (Figure 2). Lower densities were observed for other weed species commonly found in the Italian agroecosystem, such as Cirsium arvensis, Rumex crispus, Papaver rhoeas, Lolium multiflorum and Lactuca serriola. The comparison between the two wheat genotypes showed a greater ability of Kamut ${ }^{\circledR}$ for competing against weeds, such as $R$. crispus and $L$. seriola, which had a halved plant density (Figure 2). The third experimental year was marked by a quite different scenario, since the weed composition was less heterogeneous. At harvest, only three weed species were recorded in both fields (Figure 2). The most abundant species were Convolvolus arvensis (13.0-20.8 plants per square meter) and Cirsium arvense (6.618.0 plants per square meter).

As concerns productivity, the two investigated wheat varieties were comparable in terms of grain yield, with a mean value of 2.0 and 2.3 $\mathrm{t} \mathrm{ha}^{-1}$ for Kamut ${ }^{\circledR}$ and Claudio, respectively (Table 1). The observed grain yield was lower compared with most data previously reported for organically grown durum wheat (Quaranta et al., 2010; Stagnari et al., 2013) and khorasan wheat (Grausgruber et al., 2005). The main factor which influenced productivity was the cropping year. The most favourable environmental conditions occurred during the second growing season (2010/2011), which was characterised by intermediate rainfall levels from heading to harvest and a mean temperature that did not exceed $23.5^{\circ} \mathrm{C}$ during grain filling (Figure 1). Under these conditions, the grain yield obtained in 2010/2011 was $2.6 \mathrm{t} \mathrm{ha}^{-1}$, while it was comprised between 1.8 and $2.0 \mathrm{t} \mathrm{ha}^{-1}$ in the first and the third year (Table 1). The two tetraploid wheat varieties were very different in terms of plant habitus. Due to the introgression of dwarf traits in the modern lines of durum wheat varieties, the straw length was strongly reduced. Indeed, the khorasan wheat had a mean plant height which was almost double compared with that of the Claudio variety $(124.3$ and $69.2 \mathrm{~cm}$, respectively) (Table 1). Under organic management, a taller straw may offer a competitive advantage resulting from the canopy structure and other traits such as the extension of the root systems. As reviewed by Mason and Spaner (2006), previous studies reported that tall wheat varieties capture a higher percentage of photo-synthetically active radiation and are more effective at suppressing weed growth compared with dwarf genotypes. A higher competitive ability against weeds is one
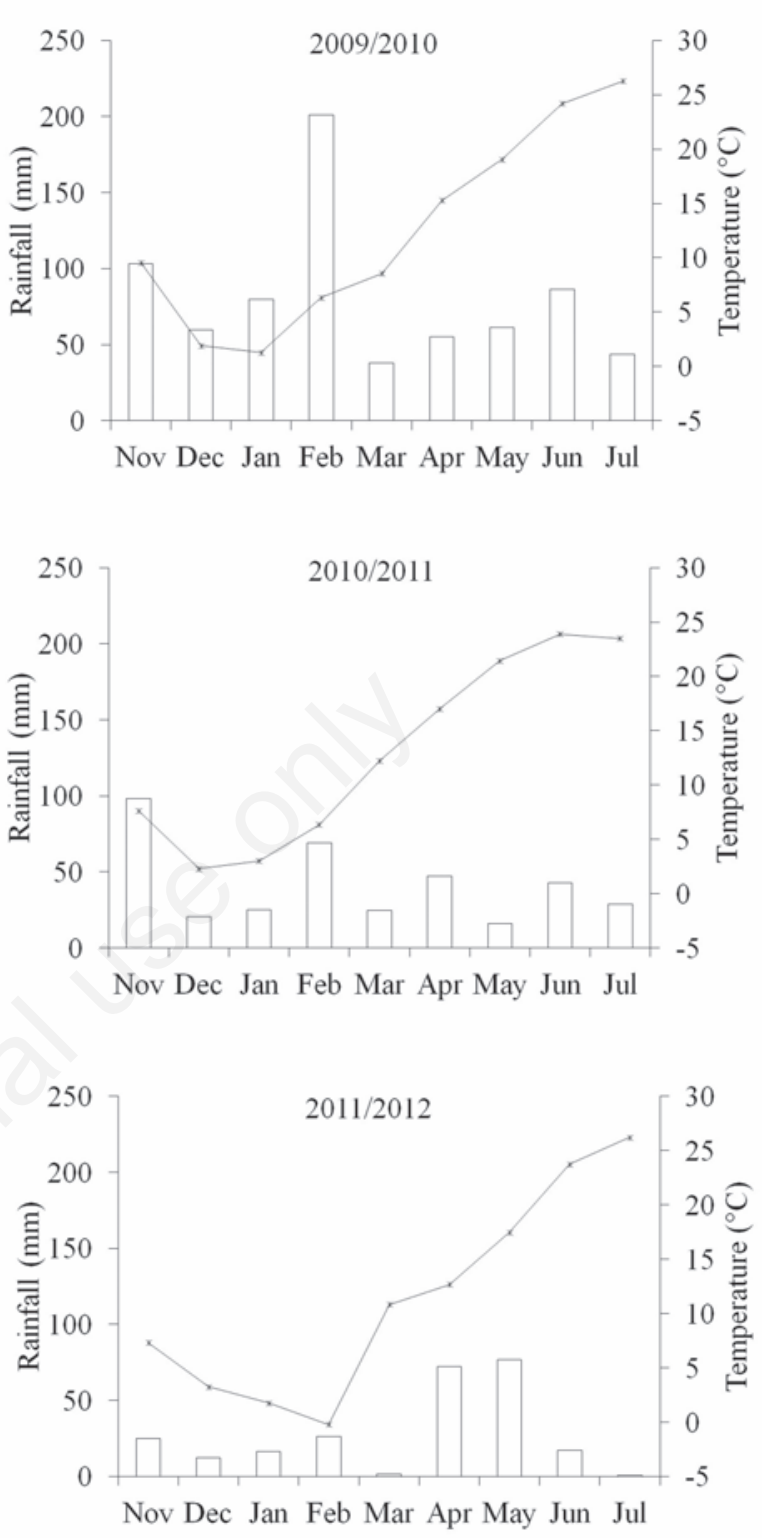

Figure 1. Monthly data recorded for rainfall $(\mathrm{mm})$ and mean temperature $\left({ }^{\circ} \mathrm{C}\right)$ during the three cropping seasons $(2009 / 2010$, $2010 / 2011,2011 / 2012$ ) at the experimental site (Argelato, Italy).

Table 1. Grain yield, plant height, straw yield, harvest index, protein content and test weight obtained for the two investigated wheat genotypes during three experimental years.

\begin{tabular}{|c|c|c|c|c|c|c|c|}
\hline & & 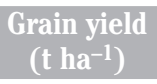 & Plant height $(\mathrm{cm})$ & $\begin{array}{c}\text { Straw yield } \\
\left(\mathrm{t} \mathrm{ha}^{-1}\right)\end{array}$ & Harvest index & $\begin{array}{l}\text { Protein } \\
\left(\mathrm{g} \mathrm{kg}^{-1}\right)\end{array}$ & $\begin{array}{l}\text { Test weight } \\
\left(\mathrm{kg} \mathrm{hL}^{-1}\right)\end{array}$ \\
\hline Variety (V) & $\begin{array}{l}\text { Kamut }^{\circledR} \\
\text { Claudio }\end{array}$ & $\begin{array}{l}2.0^{\text {ns }} \\
2.3^{\text {ns }}\end{array}$ & $\begin{array}{l}124.3^{\mathrm{a}} \\
69.2^{\mathrm{b}}\end{array}$ & $\begin{array}{l}4.8^{\mathrm{a}} \\
3.5^{\mathrm{b}}\end{array}$ & $\begin{array}{l}0.31^{\mathrm{b}} \\
0.40^{\mathrm{a}}\end{array}$ & $\begin{array}{l}120.1^{a} \\
107.8^{b}\end{array}$ & $\begin{array}{l}78.9^{n s} \\
79.1^{\text {ns }}\end{array}$ \\
\hline Year $(\mathrm{Y})$ & $\begin{array}{l}2009 / 2010 \\
2010 / 2011 \\
2011 / 2012\end{array}$ & $\begin{array}{l}1.8^{\mathrm{b}} \\
2.6^{\mathrm{a}} \\
2.0^{\mathrm{b}}\end{array}$ & $\begin{array}{l}91.0^{\mathrm{b}} \\
98.9^{\mathrm{a}} \\
98.7^{\mathrm{a}}\end{array}$ & $\begin{array}{l}3.8^{\mathrm{b}} \\
3.1^{\mathrm{b}} \\
5.5^{\mathrm{a}}\end{array}$ & $\begin{array}{l}0.34^{\mathrm{b}} \\
0.46^{\mathrm{a}} \\
0.27^{\mathrm{c}}\end{array}$ & $\begin{array}{l}108.5^{b} \\
109.6^{b} \\
123.9^{a}\end{array}$ & $\begin{array}{l}79.5^{\text {ns }} \\
79.2^{\text {ns }} \\
78.3^{\text {ns }}\end{array}$ \\
\hline Interaction & $\mathrm{Vx} Y$ & ns & ns & ns & $* * *$ & $* * *$ & ns \\
\hline
\end{tabular}

a,b,c Means followed by different letters are statistically different at $\mathrm{P}<0.05$. Interaction significance level: ${ }^{* * *} \mathrm{P}<0.001$. ns, not significant. 
of the most desirable traits for organic wheat breeder (Lammerts van Bueren et al., 2011). Our study showed that Kamut ${ }^{\circledR}$ had a greater competitive ability than the modern variety exclusively against some weed species with a small or intermediate plant height (i.e. C. arvense, $L$. seriola, $R$. crispus). Further studies will investigate in more depth the competitive effects of khorasan wheat against weeds, the factors involved in this process (i.e. height, tillering, root system extension) and their interaction to identify productive gains. The plant height values were similar during the second and third year, while a reduction of the straw length was observed during 2009/2010 (Table 1). This result was probably caused by the adverse soil conditions occurred during sowing in 2009 , due to excessive rainfall which hindered a correct field preparation and resulted in an unfavourable soil compaction. On the whole, as a consequence of its taller plant habitus, Kamut ${ }^{\circledR}$ showed the highest straw yield $\left(4.8 \mathrm{t} \mathrm{ha}^{-1}\right)$ compared to Claudio $\left(3.5 \mathrm{t} \mathrm{ha}^{-1}\right)$ (Table $1)$. The increase of the total biomass has long been considered a disadvantage, because most of the resources are expected to be concentrated on the grain and therefore on productivity. Indeed, the obtained harvest index showed the highest value for Claudio (0.40) while Kamut ${ }^{\circledR}$ had 0.31 (Table 1). In conventional farming, straw is generally considered a useless agricultural waste, although, in recent years, it has gained much attention for its utilization as a biomass source for biofuel production (Blaschek et al., 2010). Moreover, considering the closed selfsustained organization of biodynamic farms and most organic systems, straw may represent a precious resource due to its use as an essential component of compost preparation and also as soil amendment. A significant variation was observed in straw yield among the growing seasons. During 2009/2010, the low straw yield ( $\left.3.8 \mathrm{t} \mathrm{ha}^{-1}\right)$ was caused by the above-mentioned reduction in plant height. In 2010/2011, similar values were observed $\left(3.1 \mathrm{t} \mathrm{ha}^{-1}\right)$, while in the third year straw productivity was significantly higher $\left(5.5 \mathrm{t} \mathrm{ha}^{-1}\right)$ (Table 1$)$. The low straw yield during the second cropping year was due to a consistent Avena fatua $\mathrm{L}$. infestation, which led to a reduction in plant density. The genotype $\mathrm{x}$ year significant interaction showed that the Claudio durum wheat variety had always the highest $\mathrm{HI}$ and only during the second cropping season Kamut ${ }^{\circledR}$ reached similar values, while in 2009/2010 and 2011/2012 the two genotypes scored very different HIs (Figure 3 ).

Test weight (TW) results showed in general a good commercial quality of the grains throughout the crop cycles and no difference was observed between the two wheat genotypes or among cropping years with mean values comprised between 78.3 and $79.5 \mathrm{~kg} \mathrm{hL}^{-1}$ (Table 1). The milling quality of grains is mainly determined by the TW values, as they influence the flour extraction rate and are affected by grain shape and size, environment and grain damage (Troccoli et al., 2000). According to the grading system defined by UNI, the Italian national standardization body (UNI Standard 10709:1998), the observed TW values were higher than the minimum market requirement set at $75 \mathrm{~kg}$ $\mathrm{hL}^{-1}$, therefore these grains can be classified in the second quality class $\left(>78 \mathrm{~kg} \mathrm{hL}^{-1}\right)$. Previous studies reported TW values comprised between 75.4 and $83.1 \mathrm{~kg} \mathrm{hL}^{-1}$ for durum wheat grown under conventional (Troccoli and Di Fonzo, 1999) and low-input (De Vita et al., 2007a; Dinelli et al., 2013) farming. Our results also matched those of Grausgruber et al. (2005) who investigated the agronomic traits of different khorasan wheat genotypes and indicated a TW value ranging from 71.8 and $77.5 \mathrm{~kg} \mathrm{hL}^{-1}$.

The determination of the protein content showed that the accumulation of these macronutrients in the kernel varied depending on the interaction between the genotype and the growing conditions. As reported in Figure 3, the Claudio durum wheat variety had lower protein levels during the first and second year (105.0 and $94.2 \mathrm{~g} \mathrm{~kg}^{-1}$, respectively) compared with Kamut ${ }^{\circledR}$ (111.0 and $125.0 \mathrm{~g} \mathrm{~kg}^{-1}$, respectively). Conversely, during the third growing season, similar protein levels were found in both genotypes (123.4 and $124.3 \mathrm{~g} \mathrm{~kg}^{-1}$ for
Kamut $^{\circledR}$ and Claudio, respectively). These results suggested that under stressed conditions (such as excessive soil compaction in 2009/2010 and severe weed infestation in 2010/2011) Kamut ${ }^{\circledR}$ had a greater ability to maintain its usual performance, while Claudio had probably a greater susceptibility and accumulated fewer proteins in the grain. The observed protein content was in line with the values reported by Stagnari et al. (2013), but it was lower with respect to our previous study which involved old and modern durum wheat varieties grown under low-input agricultural management (Dinelli et al., 2013). The main factors affecting protein accumulation are $\mathrm{N}$ availability and soil organic matter as well as climatic conditions (Giuliani et al., 2011) and their effects, which are particularly significant under organic and biodynamic management, which excludes the use of fertilizers throughout the crop cycle.

\section{Yield components}

The yield components and some morphological traits (spikelets per spike, spike length) were also determined, as reported in Table 2 . The Kamut ${ }^{\circledR}$ kernel weight was generally higher than that of the Claudio wheat (76.9 and $44.8 \mathrm{mg}$, respectively). This finding was expected due to the higher dimensions of the Kamut ${ }^{\circledR}$ kernel with respect to the durum wheat grain. Previous studies of old and modern durum wheat varieties showed values of kernel weight similar to those observed for Claudio (De Vita et al., 2007b), while Kamut ${ }^{\circledR}$ had a significantly higher kernel weight than the values previously reported by Grausgruber $e t$ al. (2005) for several khorasan wheat accessions. Consequently, results suggested a good ripening capability of Kamut ${ }^{\circledR}$ grains and a very limited kernel shrinking. Furthermore Kamut ${ }^{\circledR}$ showed the highest number of grains per spike compared to Claudio (29.8 and 19.2, respectively) and the highest number of spikelets per spike (17.0 and 12.7, respectively) (Table 2). Both parameters varied depending on the interaction between the genotype and the cropping year (Figure 3). Indeed, during the first growing season the two genotypes showed similar and low values of grains per spike and spikelets per spike, probably as a consequence of the stressed growing conditions described above, but during the following two years Kamut ${ }^{\circledR}$ exhibited a higher phenotypic plasticity and ability to adapt to environmental changes and outperformed Claudio in terms of grains and spikelets per spike. On the whole, during 2010/2011 and 2011/2012, Kamut ${ }^{\circledR}$ showed an improved plant and spike development. In addition to its tallest plant habitus, it showed a higher spike length and spike fertility compared to the first year, while Claudio had lower values over the three experimental growing seasons (Figure 3). Giunta et al. (2007) compared the agronomic performance of old and modern durum wheat varieties and showed that the kernel weight was associated with genotypic characteristics (grain size) and did not correlate with the year of the variety release. The study reported an increased number of kernels per spike (within the range 23.4-28.0) as a results of the breeding selection aimed at improving spike fertility, but our research work showed in general lower values for Claudio. Several studies supported an increase of the preanthesis dry matter partitioning to the spikes as a consequence of the semi-dwarfing gene introgression (Brooking and Kirby, 1981; Borrell et al., 1989; Miralles and Slafer, 1995; Miralles et al., 1998; Ferrante et al., 2012), however our study highlighted that this is not suitable to low input management. This discrepancy could be explained by the lower adaptability to organic agricultural management of the Claudio variety, which fails to fully express its yield potential without a high nitrogen input. On the other hand, over the three growing seasons, Claudio showed a significantly higher spike density compared with Kamut ${ }^{\circledR}$ with an average of 331.8 against 178.0 spikes per $\mathrm{m}^{2}$ respectively (Table 2 ). The spikes per square meter observed in the Claudio variety match the previously reported ones, while Kamut ${ }^{\circledR}$ showed low values in com- 
A)

Scandix pecten

Rumex crispus

Poa pratensis

Papaver rhoeas Lolium multiflorum

Lactuca seriola

Cynodon dactylon Convolvulus arvensis

Cirsium arvense

Chenopodium album

Bromus sterilis

Avena fatua

Anagallis arvensis
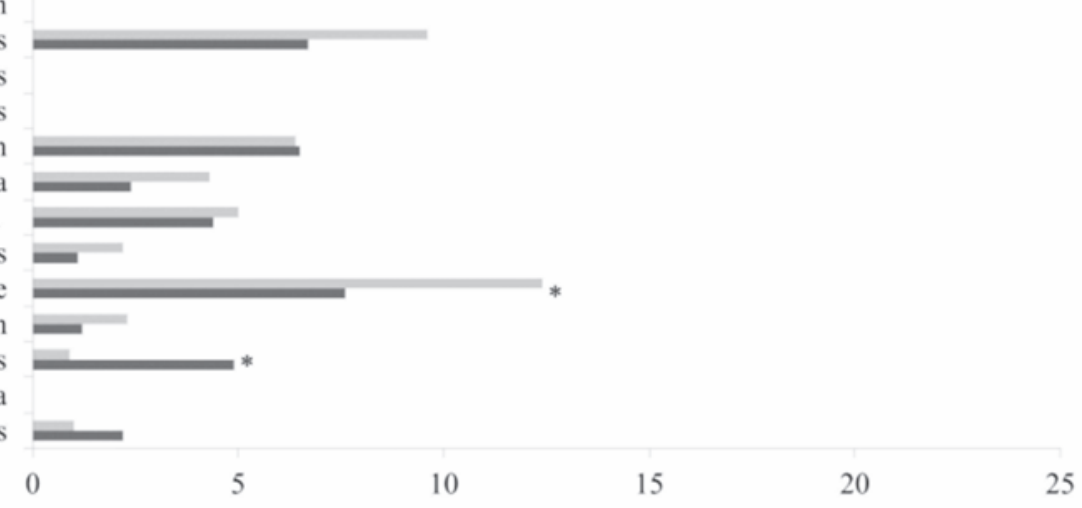

B)
Scandix pecten
Rumex crispus
Poa pratensis
Papaver rhoeas
Lolium multiflorum
Lactuca seriola
Cynodon dactylon
Convolvulus arvensis
Cirsium arvense
Chenopodium album
Bromus sterilis
Avena fatua
Anagallis arvensis

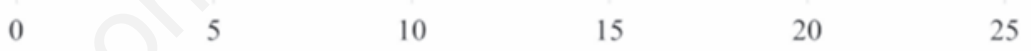

C)

Scandix pecten Rumex crispus

Poa pratensis

Papaver rhoeas

Lolium multiflorum

Lactuca seriola

Cynodon dactylon

Convolvulus arvensis

Cirsium arvense

Chenopodium album

Bromus sterilis

Avena fatua

Anagallis arvensis

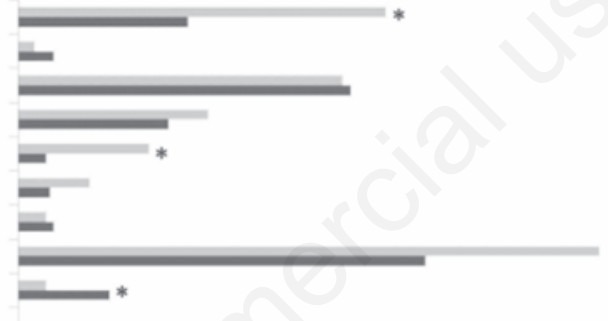

$=$ CLAUDIO $=$ KAMUT ${ }^{\circledR}$

$=$ CLAUDIO $\because$ KAMUT $^{\circledR}$

$\begin{array}{llllll}0 & 5 & 10 & 15 & 20 & 25\end{array}$

Figure 2. Plant density of weeds detected within Kamut ${ }^{\circledR}$ and Claudio experimental fields in 2009/2010 (A), 2010/2011 (B) and $2011 / 2012(\mathrm{C})$. Results are expressed as number of plants per square meter. ${ }^{*}$ Weed density significantly different between Kamut ${ }^{\circledR}$ and Claudio fields at $\mathbf{P}<\mathbf{0 . 0 5}$. 
parison with old durum wheat Italian varieties which scored 274 spikes per $\mathrm{m}^{2}$ (Royo et al., 2007). These results suggested that the modern variety had a higher tillering ability also under organic farming. A significant reduction of the measured spikes per $\mathrm{m}^{2}$ was observed during the second growing season (2010/2011) (172.8) as a consequence of the severe wild oat infestation which involved the whole experimental
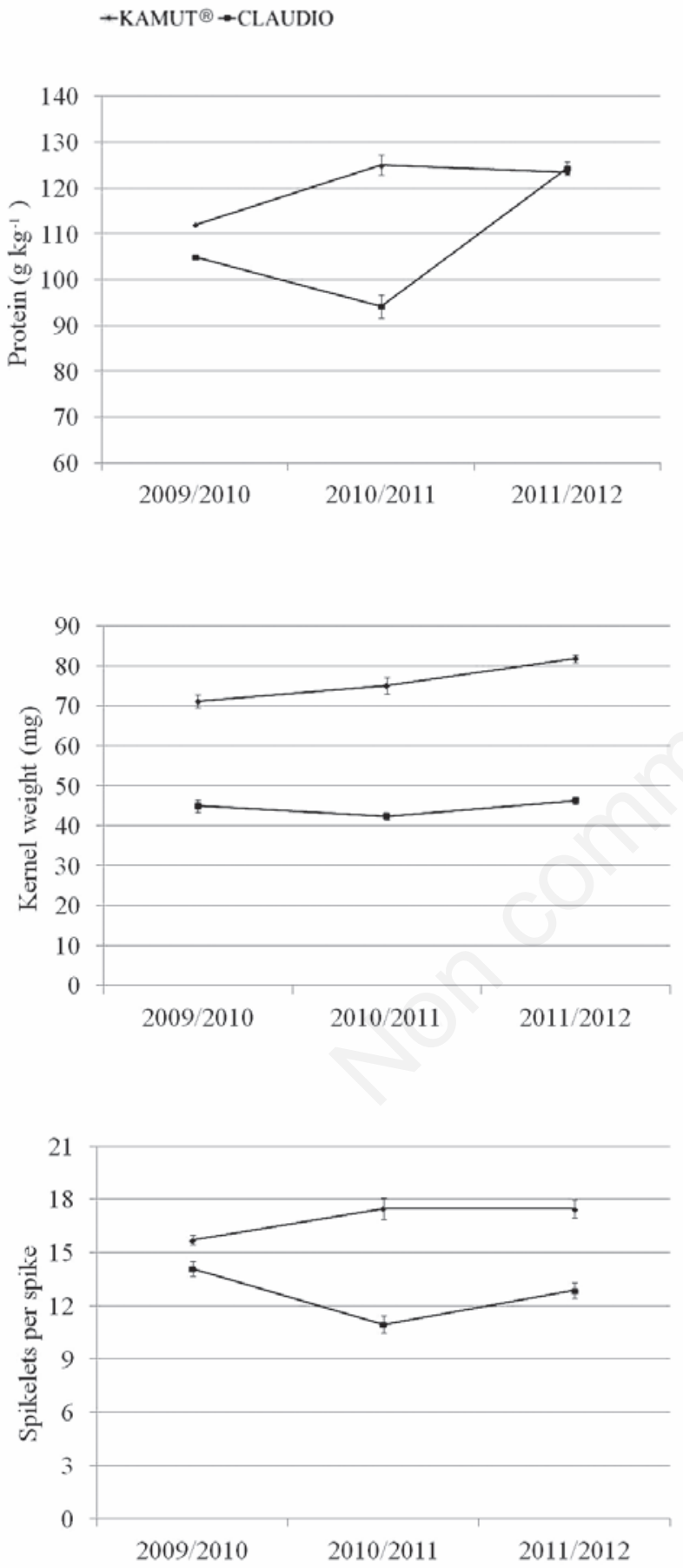

field, while the first and third years showed higher density values (311.1 and 262.0, respectively) (Table 2). In summary, considering the whole agronomic performance, the analysis of the yield components showed that Kamut ${ }^{\circledR}$ and Claudio did not differ in terms of grain yield as the lower plant density of Kamut ${ }^{\circledR}$ is compensated by its higher number of kernels per spike and its higher kernel weight.
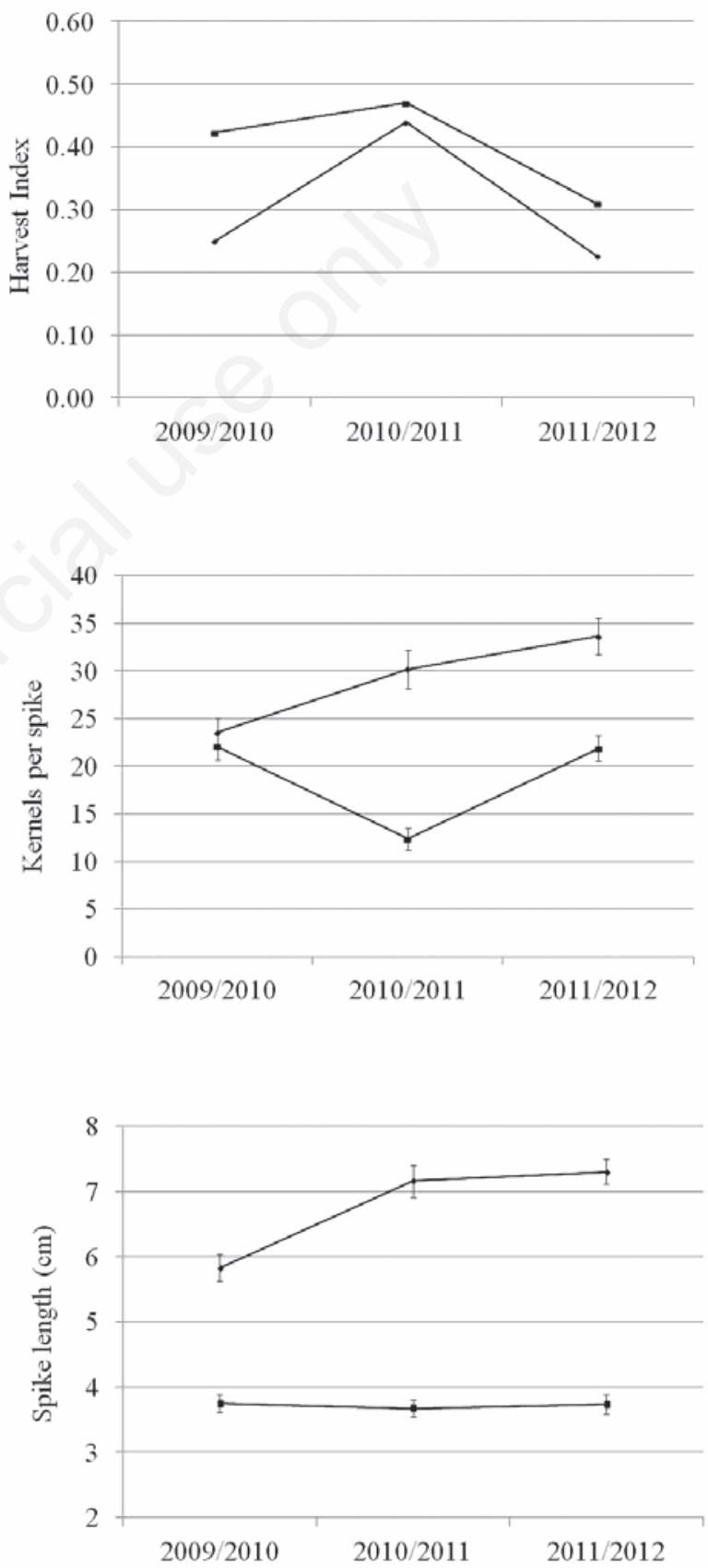

Figure 3. Significant interactions observed between genotype and cropping year for protein content, harvest index, kernel weight, kernels per spike, spikelets per spike and spike length. 
Table 2. Yield components, number of spikelets per spike and spike length obtained for the two investigated wheat genotypes during three experimental years.

\begin{tabular}{|c|c|c|c|c|c|c|}
\hline & & $\begin{array}{l}\text { Kernel weight } \\
\text { (mg) }\end{array}$ & Spikes per square meter & Kernels per spike & Spikelets per spike & $\begin{array}{l}\text { Spike length } \\
(\mathrm{cm})\end{array}$ \\
\hline Variety (V) & $\begin{array}{l}\text { Kamut }^{\circledR} \\
\text { Claudio }\end{array}$ & $\begin{array}{l}76.9^{\mathrm{a}} \\
44.8^{\mathrm{b}}\end{array}$ & $\begin{array}{l}178.0^{\mathrm{b}} \\
331.8^{\mathrm{a}}\end{array}$ & $\begin{array}{l}29.8^{\mathrm{a}} \\
19.2^{\mathrm{b}}\end{array}$ & $\begin{array}{l}17.0^{\mathrm{a}} \\
12.7^{\mathrm{b}}\end{array}$ & $\begin{array}{l}6.8^{\mathrm{a}} \\
3.7^{\mathrm{b}}\end{array}$ \\
\hline Year $(\mathrm{Y})$ & $\begin{array}{l}2009 / 2010 \\
2010 / 2011 \\
2011 / 2012\end{array}$ & $\begin{array}{l}58.1^{\mathrm{b}} \\
58.3^{\mathrm{b}} \\
64.1^{\mathrm{a}}\end{array}$ & $\begin{array}{l}311.1^{\mathrm{a}} \\
172.8^{\mathrm{c}} \\
262.0^{\mathrm{b}}\end{array}$ & $\begin{array}{l}22.8^{\mathrm{b}} \\
21.0^{\mathrm{b}} \\
27.8^{\mathrm{a}}\end{array}$ & $\begin{array}{l}14.9^{\mathrm{ns}} \\
14.1^{\mathrm{ns}} \\
15.2^{\mathrm{ns}}\end{array}$ & $\begin{array}{l}4.8^{\mathrm{b}} \\
5.4^{\mathrm{a}} \\
5.5^{\mathrm{a}}\end{array}$ \\
\hline Interaction & $\mathrm{VxY}$ & ns & ns & $* * *$ & $* * *$ & $* * *$ \\
\hline
\end{tabular}

a,b,c Means followed by different letters are statistically different at $\mathrm{P}<0.05$. Interaction significance level: ${ }^{* * *} \mathrm{P}=<0.001$. ns, not significant.

\section{Mycotoxyns analysis and effects of cleaning proce- dures on semolina contamination}

The analysis of the mycotoxin content of wholegrain semolina showed the remarkable effect of weather conditions on contamination levels. The first growing season (2009/2010) presented a quite favourable environmental situation for head blight Fusarium development in the final phase of the crop cycle (May-July) with wet and rather warm conditions. On the contrary, during the second and third year (2010/2011, 2011/2012), the drier conditions probably limited fungi infection and mycotoxin production. This is reflected in the DON levels observed for Kamut ${ }^{\circledR}$ and Claudio grains as shown in Figure 4. Grains harvested in the first year had a high mycotoxin content ranging from 1.07 to $1.31 \mathrm{mg} \mathrm{kg}^{-1}$ (for Kamut $^{\circledR}$ and Claudio grains, respectively). During 2010/2011, Kamut ${ }^{\circledR}$ and Claudio showed in general lower values ( 0.44 and 0.35 , respectively), while in 2011/2012 a different trend in DON accumulation was observed for the two genotypes: on average, Claudio had $0.75 \mathrm{mg} \mathrm{kg}^{-1}$ of DON, while Kamut ${ }^{\circledR}$ had a significantly lower amount $\left(0.18 \mathrm{mg} \mathrm{kg}^{-1}\right)$ (Figure 4). For the third year, the weather data (Figure 1) showed a high level of precipitation in May, which corresponds to the anthesis phase, while dry conditions were observed in June and July. In this climatic situation, the modern durum wheat variety Claudio seemed to be more susceptible to the Fusarium infection, particularly during the flowering period. Indeed, the higher rainfall and humidity levels during flowering had shown previously to induce a higher production of mycotoxins (Parry et al., 1995). On the whole, all the investigated grain samples showed a good hygienic and sanitary quality with DON values under the legal limit set for unprocessed durum wheat $\left(1.75 \mathrm{mg} \mathrm{kg}^{-1}\right)$ by the European Commission Regulation No. 1126/2007 (European Commission, 2007). Fungi and mycotoxins are expected to be mainly accumulated on the outer layer of the wheat kernel and therefore cereal pre-milling processing, which for instance includes sorting, cleaning, milling and thermal processes, may have effects on DON stability and concentration (Brera et al., 2006; Cheli et al., 2010; Cheli et al., 2013). One commonly used strategy to reduce semolina mycotoxins is debranning prior to milling. However, this strategy does not suit the production of stone-ground wholegrain semolina. In order to understand how alternative procedures to debranning may help reduce DON levels, grains of Kamut ${ }^{\circledR}$ and Claudio harvested in 2009/2010 and 2010/2011 were water-cleaned and brushed at different frequency speeds $(20-90 \mathrm{~Hz})$ and then analysed to assess their mycotoxin content.

The reduction of DON levels after the water-cleaning treatment was observed exclusively in the Kamut ${ }^{\circledR}$ grain $(46 \%$ mycotoxin reduction compared with untreated control), while the Claudio samples showed no significant variations (Figure 5). This finding suggested that most

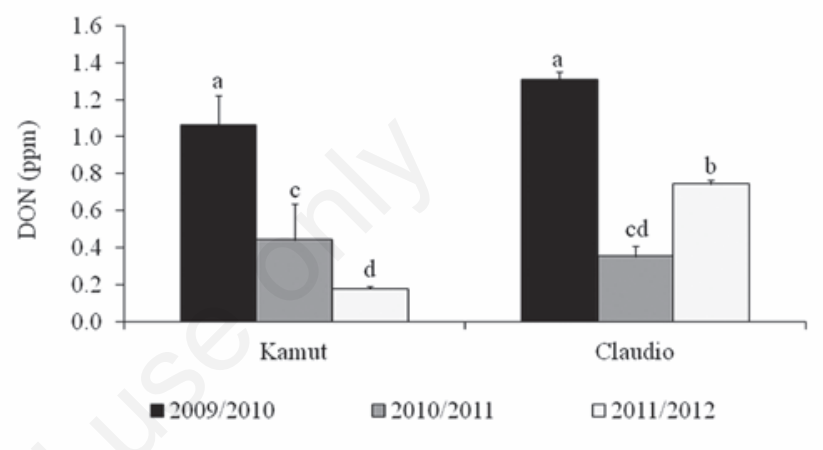

Figure 4. Deoxynivalenol contamination of Kamut ${ }^{\circledR}$ and Claudio expressed as $\mathrm{mg}$ per kilogram of wholegrain semolina ( \pm standard deviation). Different letters mean statistically different values at $\mathrm{P}<0.05$.

of the mycotoxins were accumulated on the surface of the Kamut ${ }^{\circledR}$ grain and therefore could be easily removed by washing, while the Claudio grain probably had a deeper kernel infestation. As regards the brushing process, low frequency values (from 20 to $30 \mathrm{~Hz}$ ) did not decrease the mycotoxin concentration in the Kamut ${ }^{\circledR}$ wholegrain semolina (Figure 5A). On the contrary, an increase of the DON levels was observed in the Claudio semolina brushed at $20,25,30$ and $60 \mathrm{~Hz}$, which reached a content of $2.02 \mathrm{mg} \mathrm{kg}^{-1}$ in the $2009 / 2010$ samples. At higher rotation powers, a different trend was observed when comparing the two wheat genotypes (Figure $5 \mathrm{~A}$ ). At $60 \mathrm{~Hz}$, the contamination of the Kamut ${ }^{\circledR}$ grain was halved, while at $90 \mathrm{~Hz}$ it was reduced at the detection limit $\left(0.07 \mathrm{mg} \mathrm{kg}^{-1}\right)$, but this was not observed for the Claudio variety, which showed a grain contamination level unaffected at both $60 \mathrm{~Hz}$ and $90 \mathrm{~Hz}$. Conversely, the efficiency of 60 and $90 \mathrm{~Hz}$ brushing speeds in reducing the DON levels was confirmed for both genotypes in grains harvested during the following cropping year (2010/2011) (Figure 5B), since all samples generally showed a lower DON contamination than the maximum legal threshold value. The differences observed between Kamut ${ }^{\circledR}$ and Claudio in response to the cleaning and brushing treatment may be related to a different texture and composition of the bran layers. Results suggested that the Kamut ${ }^{\circledR}$ pericarp may exert higher resistance to fungi penetration and mycotoxyns may be mainly accumulated in the outermost layers and therefore can be partially removed during the cleaning procedures. 
A)

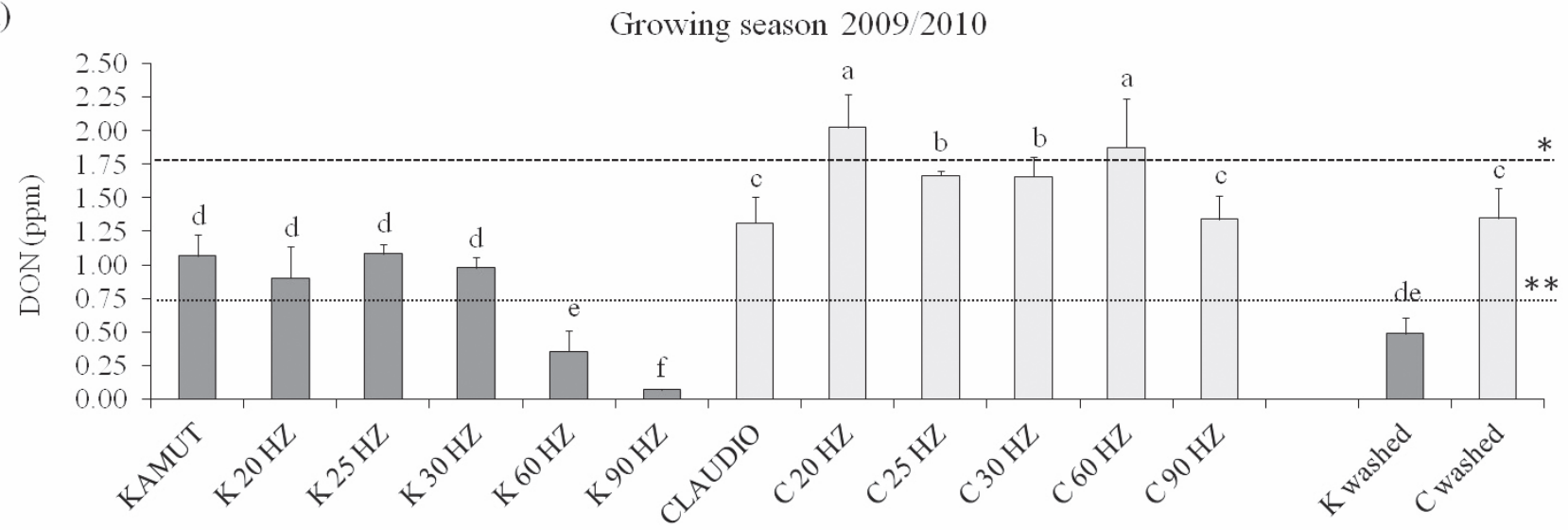

B)

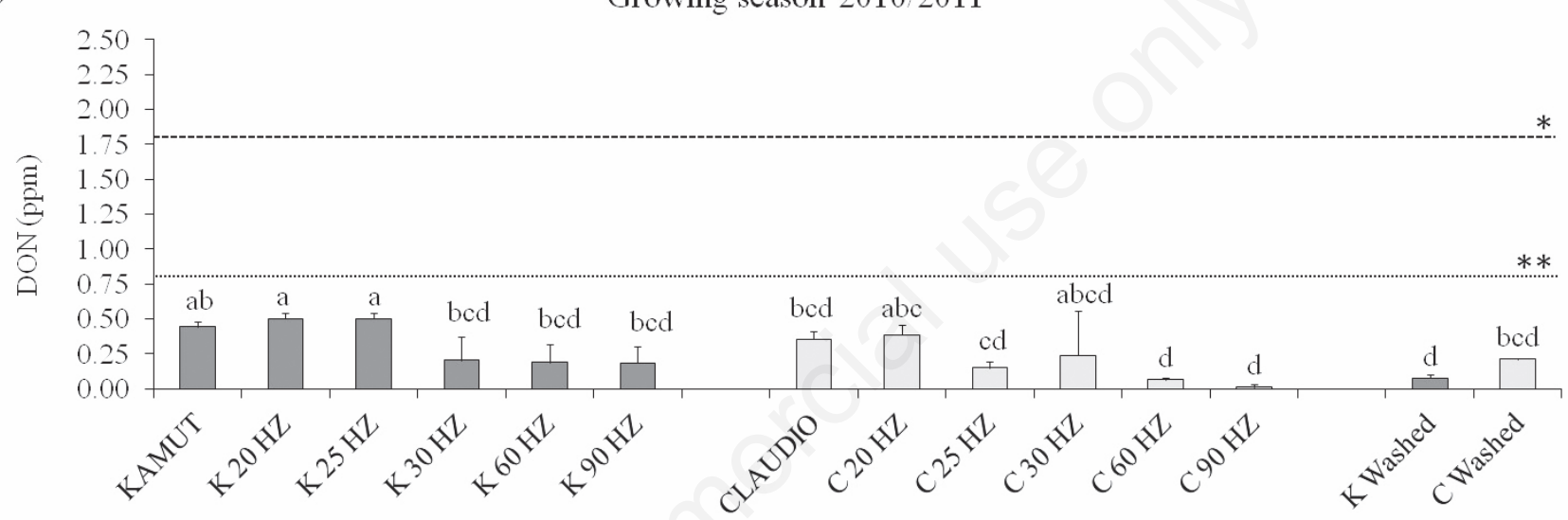

Figure 5. Mycotoxin content (DON) of Kamut ${ }^{\circledR}$ and Claudio grains harvested during the 2009/2010 (A) and 2010/2011 (B) growing seasons, brushed at five different rotation powers $(20,25,30,60,90 \mathrm{HZ})$. Different letters indicate mean statistically different values at $\mathrm{P}<0.05$. ${ }^{*}$ Threshold limit set by EU regulation $1126 / 2007$ for unprocessed durum wheat $(1.75 \mathrm{mg} / \mathrm{kg})$; ${ }^{* *}$ threshold limit set by $\mathrm{EU}$ regulation $1126 / 2007$ for cereal flour $(0.75 \mathrm{mg} / \mathrm{kg})$.

\section{Conclusions}

Our three-year research activity provided a complete description of the agronomic performance of two durum wheat genotypes grown strictly under low-input management. Although the observed productivity was quite low, the experimental trials allowed for a comparison between khorasan wheat and durum wheat in terms of agronomic traits, yield components and mycotoxin contamination, providing useful insights for the evaluation of their potential adaptability to the organic farming sector. Results showed that khorasan wheat and durum wheat varieties had similar productivity levels. The yield components showed that the modern cultivar had a higher plant density than Kamut ${ }^{\circledR}$, but this discrepancy was compensated by the higher number of kernels per spike and the higher kernel weight of Kamut ${ }^{\circledR}$. The modern durum wheat variety, which is expected to possess improved spike fertility, seemed to fail expressing its yield potential when grown under organic farming management. These results highlight the need to develop wheat genotypes that can offer an adequate performance without nitrogen inputs by selecting specific traits, such as kernel weight, spike length and kernels/spike, thus leading to productivity gains. The investigated wheat genotypes showed a good hygienic and sanitary quality with mycotoxin levels (DON) below the maximum threshold values set by the European Union regulation. In addition, our study highlighted that pre-milling cleaning procedures, such as water-washing and brushing can significantly reduce semolina contamination. These methods showed to be particularly efficient with Kamut ${ }^{\circledR}$ wholegrain semolina, suggesting that DON were accumulated at more superficial levels than the durum wheat variety. On the whole, the study highlighted that the choice of the wheat genotype and the adoption of good agronomic practices play a key role in the control of Fusarium infection and mycotoxin contamination, especially in agronomic systems in which no fungicides are applied to the crops. The research work provided additional knowledge on the traits that may be further improved to meet the request of low input sector and the potential adaptability of wheat genotypes to the organic agricultural management. 


\section{References}

AACC, 1995. Approved method of American Association of Cereal Chemists. $9^{\text {th }}$ ed. The Association, St. Paul, MN, USA.

Benedetti S, Primiterra M, Tagliamonte MC, Carnevali A, Gianotti A, Bordoni A, Canestrari F, 2012. Counteraction of oxidative damage in the rat liver by an ancient grain (Kamut brand khorasan wheat). Nutrition 28:436-41.

Blaschek H, Ezeij T, Scheffran JB, 2010. Biofuels from agricultural wastes and byproducts. Wiley-Blackwell Publishing, Ames, IA, USA.

Borrell AK, Incoll ID, Simpson RJ, Dalling MJ, 1989. Partitioning of dry matter and the deposition and use of stem reserves in a semi-dwarf wheat crop. Ann. Bot. 63:527-39.

Brera C, Catalano C, De Santis B, Debegnach F, De Giacomo M, Pannunzi E, Miraglia M, 2006. Effects of industrial processing on the distribution of aflatoxins and zearalenone in corn-milling fractions. J. Agric. Food Chem. 54:5014-9.

Brooking IR, Kirby EJM, 1981. Interrelationships between stem and ear development in winter wheat: the effects of a Norin 10 dwarfing gene, Gai/Rht 2 . J. Agric. Sci. 97:527-39.

Cheli F, Campagnoli A, Ventura V, Brera C, Berdini C, Palmaccio E, Dell'Orto V, 2010. Effects of industrial processing on the distributions of deoxynivalenol, cadmium and lead in durum wheat milling fractions. Food Sci. Technol. 43:1050-7.

Cheli F, Pinotti L, Rossi L, Dell'Orto V, 2013. Effect of milling procedures on mycotoxin distribution in wheat fractions: A review. Food Sci. Technol. 54:307-14.

De Vita P, Di Paolo E, Fecondo G, Di Fonzo N, Pisante M, 2007b. Notillage and conventional tillage effects on durum wheat yield, grain quality and soil moisture content in southern Italy. Soil Till. Res. 92:69-78.

De Vita P, Mastrangelo AM, Codianni P, Fornara M, Palumbo M, Cattivelli L, 2007a. Bio-agronomic evaluation of old and modern wheat, spelt and emmer genotypes for low-input farming in Mediterranean environment. Ital. J. Agron. 3:291-302.

Dinelli G, Marotti I, Di Silvestro R, Bosi S, Bregola V, Accorsi M, Di Loreto A, Benedettelli S, Ghiselli L, Catizone P, 2013. Agronomic, nutritional and nutraceutical aspects of durum wheat (Triticum durum Desf.) cultivars under low input agricultural management. Ital. J. Agron. 8:85-93.

Edwards SG, 2009. Fusarium mycotoxin content of UK organic and conventional wheat. Food Addit. Contam. 26:496-506.

European Commission, 2007. Commission Regulation (EC) No 1126/2007 of 28 September 2007 amending Regulation (EC) No $1881 / 2006$ setting maximum levels for certain contaminants in foodstuffs as regards Fusarium toxins in maize and maize products. In: Official Journal, L 255, 29/9/2007, pp 14-17. Available from: http://eur-lex.europa.eu/LexUriServ/Lex UriServ.do?uri=0J:L:2007: 255:0014:0017:EN:PDF

Fardet A, 2010. New hypotheses for the health-protective mechanisms of whole-grain cereals: What is beyond fibre? Nutr. Res. Rev. 23:65134.

Ferrante A, Savin R, Slafer GA, 2012. Differences in yield physiology between modern, well adapted durum wheat cultivars grown under contrasting conditions. Field Crops Res. 136:52-64.

Giuliani MM, Giuzio L, De Caro A, Flagella Z, 2011. Relationships between nitrogen utilization and grain technological quality in durum wheat: II. Grain yield and quality. Agron. J. 103:1668-75.

Giunta F, Motzo R, Pruneddu G, 2007. Trends since 1900 in the yield potential of Italian-bred durum wheat cultivars. Eur. J. Agron. 27:12-24.

Grausgruber H, Oberforster M, Ghambashidze G, Ruckenbauer P, 2005. Yield and agronomic traits of Khorasan wheat (Triticum turanicum Jakubz.). Field Crops Res. 91:319-27.

ISMEA (Istituto di Servizi per il Mercato Agricolo Alimentare), 2012. Rapporto Sinab (Sistema d'Informazione Nazionale sull'Agricoltura Biologica) Bio in cifre. Available from: http://www.sinab.it Accessed: 19/12/2013.

Lammerts van Bueren ET, Jones SS, Tamm L, Murphy KM, Myers JR, Leifert C, Messmer MM, 2011. The need to breed crop varieties suitable for organic farming using wheat, tomato and broccoli as examples: a review. NJAS-Wagen. J. Life Sci. 58:193-205.

Marotti I, Bregola V, Aloisio I, Di Gioia D, Bosi S, Di Silvestro R, Quinn R, Dinelli G, 2012. Prebiotic effect of soluble fibres from modern and old durum-type wheat varieties on Lactobacillus and Bifidobacterium strains. J. Sci. Food Agric. 92:2133-40.

Mason HE, Spaner D, 2006. Competitive ability of wheat in conventional and organic management systems: a review of the literature. Can. J. Plant Sci. 86:333-43.

Miralles DJ, Katz SD, Colloca A, Slafer GA, 1998. Floret development in near isogenic wheat lines differing in plant height. Field Crop Res. 59:21-30.

Miralles DJ, Slafer GA, 1995. Yield, biomass and yield components in dwarf, semi-dwarf and tall isogenic lines of spring wheat under recommended and late soling dates. Plant Breeding 114:392-6.

Murphy PA, Hendrich S, Landgren C, Bryant CM, 2006. Food mycotoxins: an update (scientific status summary). J Food Sci. 71:51-65.

Parry DW, Jenkinson P, McLeod L, 1995. Fusarium ear blight (scab) in small grain cereals - A review. Plant Pathol. 44: 207-38.

Piergiovanni AR, Simeone R, Pasqualone A, 2009. Composition of whole and refined meals of Kamut under southern Italian conditions. Chem. Eng. Trans. 17:891-6.

Quaranta F, Amoriello T, Aureli G, Belocchi A, D’Egidio MG, Fornara M, Melloni S, Desidrio E, 2010. Grain yield, quality and deoxynivalenol (DON) contamination of durum wheat (Triticum durum Desf.): results of national networks in organic and conventional cropping systems. Ital. J. Agron. 4:353-66.

Royo C, Alvaro F, Martos V, Ramdani A, Isidro J, Villegas D, Garcia del Moral LF, 2007. Genetic changes in durum wheat yield components and associated traits in Italian and Spanish varieties during the 20th century. Euphytica 155:259-70.

Stagnari F, Codianni P, Pisante M, 2008. Agronomic and kernel quality of ancient wheats grown in central and southern Italy. Cereal Res. Commun. 36: 313-26.

Stagnari F, Onofri A, Codianni P, Pisante M, 2013. Durum wheat varieties in $\mathrm{N}$-deficient environments and organic farming: a comparison of yield, quality and stability performances. Plant Breeding 132:266-75.

Troccoli A, Borrelli GM, De Vita P, Fares C, Di Fonzo N, 2000. Durum wheat quality: a multidisciplinary concept. J. Cereal Sci. 32:99-113.

Troccoli A, Di Fonzo N, 1999. Relationship between kernel size features and test weight in Triticum durum. Cereal Chem. 76:45-9.

UNI (Ente Italiano di Normazione), 1998. Cariossidi di grano duro. Requisiti qualitativi, classificazione e metodi di prova. UNI 10709:1998. UNI, Milano, Italy. 